\title{
Preliminary study of indonesia capital city relocation based on disaster mitigation principle with mental model approach
}

\author{
Hanif Nur Azhar ${ }^{1 *}$, Helmya Hilda Putri Fatima ${ }^{1}$, and Isna Nufussilma Tamas ${ }^{1}$ \\ ${ }^{1}$ Environmental Engineering Department, Bandung Institute of Technology, Indonesia
}

\begin{abstract}
Jakarta (capital city of Indonesia) is threatened by potential disaster in the future. Furthermore, scientists predict that Jakarta will sink in 2050. Currently, northern Jakarta has sunk by 2.5 meters in a period of 10 years due to human activities along with natural conditions which causes disaster, such as land subsidence by infrastructure construction and excessively use of groundwater, poor drainage systems, and a constant sea level rise. Government of Indonesia also considers several effects of capital city relocation such as changes in the fields of economy, politics, defense, security, social, culture, and environment. This study examine environmental aspects considered in the capital city relocation, associated to disaster mitigation using a mental model approach. Environmental aspects as the main factors are from human activities which caused by decrease of natural carrying capacity and natural conditions itself that caused an increase of disaster vulnerability. Both of these aspects are elaborated to compile a study of capital city relocation based on the disaster prevention principle. The study through a mental framework model can assist the government and relevant stakeholders in the formulation of capital city relocation.Jakarta, as the capital city of Indonesia, several sectors has facing rapid growing development, particularly in the sector of trade, industry, transportation, real estate, and many others
\end{abstract}

\section{Introduction}

Indonesian capital city, Jakarta, has an estimated population of around 10.2 million (BPS, 2019), inhabiting area of about $662.33 \mathrm{~km}^{2}$. Jakarta is located on the northern of west java coastal area with the coordinate of about $-6^{\circ} 150$ (latitude) and $106^{\circ} 500$ (longitude) (Abidin et al., 2011).

Jakarta, as the capital city of Indonesia, face a rapid growing development, particularly in the sector of trade, industrial, transportation, real estate, and many others. Firman \& Dharmapatni (1994) in their previous research conducted that urban development has some negative impacts such as (1) alteration of agricultural areas into residential or industrial areas, (2) rapid reduction of urban green spaces as ecological function for water recharge area for Jakarta, (3) excessive groundwater usage due to urban/industrial growth and population, (4) complex solid waste management system within the city, (5) air pollution problem persisting in Jakarta. In addition, there are several disaster risks triggered by climate change, human activities, and seismic activity in Jakarta.

Joko Widodo, President of the Republic of Indonesia announced new designed capital city to replace Jakarta in 26 August 2019, located in Kutai Kartanegara Regency alongside with North Penajem Pasar Regency, East Kalimantan. Government of Republic Indonesia argues East Kalimantan has several benefits such as (1) Two major international airport is close to the proximity of capital city (Sultan Aji Muhammad Sulaiman International Airport and Aji Pangeran Tumenggung Pranoto), (2) East Kalimantan has the access of Balikpapan-Samarinda toll road which extends 99.35 kilometers $(\mathrm{km})$ long, (3) capital city candidate also has access to Port of Semayang, (4) East Kalimantan also has network of energy and clean water resources, (5) East Kalimantan has heterogenous demographic structure, it means most of East Kalimantan population are migrants and adaptable with the changes, (6) Indonesia Archipelagic Sea Lanes (ALKI II) also crosses in East Kalimantan delineation location. Furthermore, Indonesian Agency for Meteorological, Climatological and Geophysics (BMKG, 2019) claims Kalimantan has relatively low seismic activity, as Kalimantan region has lesser number of active faults and situated far from subduction zone (megathrust).

Despite from all benefits government of Indonesia already emphasize in every national dialogue and mass media, there is still strong opposition from several people and experts, arguing that the relocation of the capital city of Indonesia will be redundant, as the big sum of money will be splashes for building capital city and applying all the technology for the smart city concept, while Jakarta 1 will be abandoned. Some environmentalists also express their concern as deforestation rate will be higher as future rapid infrastructure development consuming vast amount of forest area in Kalimantan.

Capital city relocation is not a new phenomenon. Several countries including United States of America, Turkey, Brazil, Australia have been relocating its capital city. One of ongoing progress of capital city relocation is South Korea. According to studies conducted by Kwon (2015), the purpose of capital city relocation in South Korea is to reorganize its national development strategy to stabilize its economic development.

\section{Literature Review}

\subsection{Climate Related Disaster}

Urban population in low- and middle-income countries is highly suspected with the future climate change risk in the future (Darmanto et al, 2019). Although there is no clear

* Corresponding author: hnazhar425@gmail.com 
evidence in the relations of climate change and serious flooding disaster in Jakarta, obviously the city is vulnerable to climate related disaster (Firman et al, 2011). In recent years, Jakarta suffered from serious flooding disaster and monsoon rains, particularly in the years 1996, 2002, 2007, 2013, and 2014. Extreme flooding also expected to be severe due to the impact of excessive land conversion and climate change (Takagi et al, 2016).

As stated in The Intergovernmental Panel on Climate Change Special Report of Global Warming of $1.5^{\circ} \mathrm{C}$ (or IPCC SR15), coastal urban area is highly susceptible to extreme water level due to rising sea level which lead to increasing probability of flooding and infrastructure damage (unless mitigation is undertaken). As climate change affecting ice volume and sea level, coastal area will suffer from flooding caused by tidal inundation and even permanent flooding (Andreas et al, 2018). Northern Jakarta is highly exposed to coastal hazard risk because its directly adjacent to the sea, and one of the main threats is when the inland is flooded because of incoming water from the Sea (locally known as Rob) (Latief et al., 2018). Consequently people and ecosystem within the coastal area will suffer from the effect, with probability leads to evacuate from their homeland (Andreas et al, 2018).

Furthermore, the risk is increasing as the northern part of Jakarta area predicted to be subsided with the average rate of land subsidence of 5.7-5.4 cm/year for year 20202040 , according to study conducted by Abidin et al (2016).

\subsection{Land Subsidence}

Land subsidence phenomenon affecting many large urban cities worldwide triggered either by human activities or natural factor (Abidin et al., 2015). According to several studies conducted by Murdohardono \& Tirtomihardjo (1993), Murdohardono \& Sudarsono (1998) Harsolumakso (2001), Hutasoit (2001), there are four types of land subsidence likely happened in Jakarta, such as subsidence due to excessive groundwater extractions, subsidence caused by construction loads, subsidence triggered by natural consolidation of alluvial soil, and geotectonic subsidence.

Land subsidence phenomenon combined with sea level rise, heavy rain or storms sharply increase risk of flooding from the major river and extend the coastal area affected by storm surges and tidal inundation (Chaussard et al, 2013).

Urban development process is likely associated with land subsidence phenomenon currently occurring in Jakarta (Abidin et al., 2011). Unbalance land usage due rapid building development and infrastructure construction in Jakarta already posed an imminent threat to the city sustainability, as the effect of land subsiding happened such as cracking in the permanent construction, expansion of flooding area, and lower groundwater level, and inland seawater intrusion risk increased (Abidin et al., 2001, 2011).

\subsection{Seismic Related Disaster}

Jakarta is located in Sunda Arc (part of Java Island). Jakarta stretches from Andaman Sea in the northwest to Banda Sea in the East (Cipta, 2018). According to research conducted by Simons et al (2007) and Hall (2009) with GPS measurement, Australian Plate is moving forward with rate of 67 to $70 \mathrm{~mm} / \mathrm{year}$ and subducting beneath the Eurasian Plate. Referring to a report from the National Center for Earthquake Studies in 2017, It is estimated earthquake as large as $8.7 \mathrm{M}_{\mathrm{w}}$ can be generated from Sunda Strait-West Java Segment of the Sunda Subduction Zone.

Furthermore, from GPS observation conducted by Koulali et al (2017) indicates presence active fault crosses about 25 kilometers south of Jakarta, extending from the Baribis Fault which potentially trigger earthquakes in the future. Earthquake ground modelling (preliminary result) conducted by Cipta et al (2018) also suggest that deep basin structure in Jakarta greatly enhanced seismic hazard. Combined with the Jakarta proximity to the source of Earthquake (megathrust or active fault) and historical earthquake that demolished Jakarta century ago, it should be considered for the fate of Jakarta in the future.

\section{Methodology}

\subsection{Overview}

As a tool for construct preliminary ideas and connecting related component/knowledge of Indonesia capital city relocation, mental model approach has been applied. These knowledge and component are extracted based from literature review, structural interview with the experts, and perspective of the researcher as Indonesia citizen regarding these issue.

\subsection{Mental Model and Decision Making}

Mental model is one of the tools for unifying every perspective in capital city relocation. It can formulate modeling from any perspective (holistic study). A mental model is the networks of causes and effects that describe how a system operates, along with the boundary of the model. Usually, humans are actively constructed (modeled) by senses and brain (Sterman, 2000).

A principal drawback in mental models is a propensity to think of cause and effect as local and immediate. One of the unwanted effects in the decision making based on mental model is wrong interpretation that causing policy resistant (Sterman, 2000).

Decision making based on the values and preferences of the decision-maker. The process consists of a decision problem definition, deciding, and decision execution (Mordecai, 2014). The principle of decision making refers to the rules that determine the behavior in the system. The conceptual framework used as a decision making support to identify the problem in the system (Bettinger, 2001). One of conceptual frameworks used in decision making known as system structure diagram. 


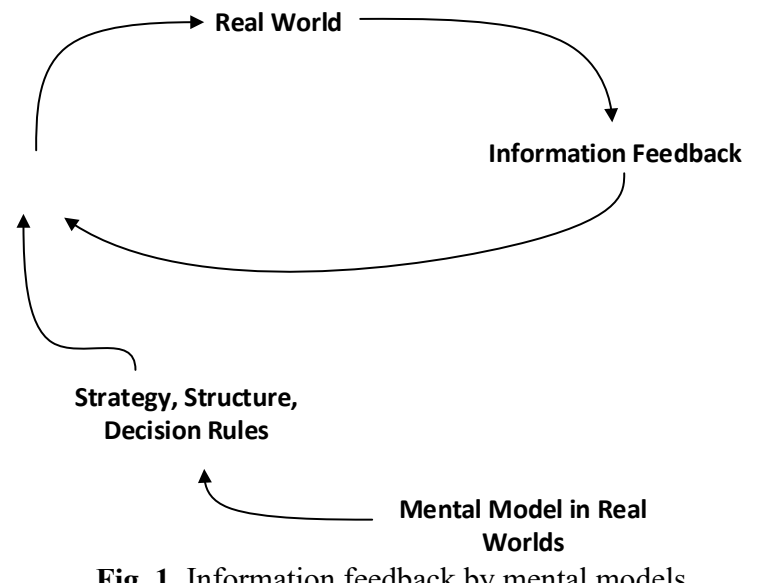

Fig. 1. Information feedback by mental models (Sterman, 2000)

\subsubsection{System Structure Diagram}

Mental model is one of the tools for establishing systemic thinking. Systemic thinking seeking the means to improve the mental models and thereby improve the quality of decision making that are based on mental models.

Mental models often have a failure to include the critical feedbacks defining the dynamics systems. So there was needed for some diagramming tools to capture the systems structure, including system structure diagram, causal loop diagrams and stock and flow maps.

System structure diagram is one of the development tools for modelling different parts of a system, from the perspective of how the individual parts interact with the other components within the system. This tools also visualizes how system works from the initial condition, processing, and desired outputs.

\subsection{Qualitative Method}

Qualitative method in this study aims to get primer data. One of the techniques to obtain the data in this study is an interview with an expert. A structural interview have purpose to get data and opinion from an expert about assessment of capital city relocation. Interviews were conducted to geological expert, geodesy expert, and environmental modelling expert from Bandung Institute of Technology.

Beside that, data in this study were arranged through National Discussion followed by author. National Discussion titled "Intelligent Innovation of Planning and Design New Capital City" and held by Central City Innovation and Smart Community (PIKKC), Bandung Institute of Technology at August 27th 2019. This national discussion presenting the Minister of National Development Planning Agency; Deputy of Administrative and Bureaucratic Reform Ministry; Head of PIKKC; and Professor of Urban Planning and Design, Bandung Institute of Technology.

\section{Result and Discussion}

This section discussed the state of knowledge regarding the mental model as a solution for the preliminary study used structure of the conceptual framework.

\subsection{Mental Model}

Mental models of the systems include (1) component model (2) relationships between those components, and (3) repeating pattern. The model identified key components in the system to understand which components and actions probably, or unlikely to be productive (Westbrook, 2006). Each component has its own data, properties, and functions or roles. In Fig. 2, components of the model consist of data and property, contain anything related to the issues discussed in Indonesia's capital city relocation

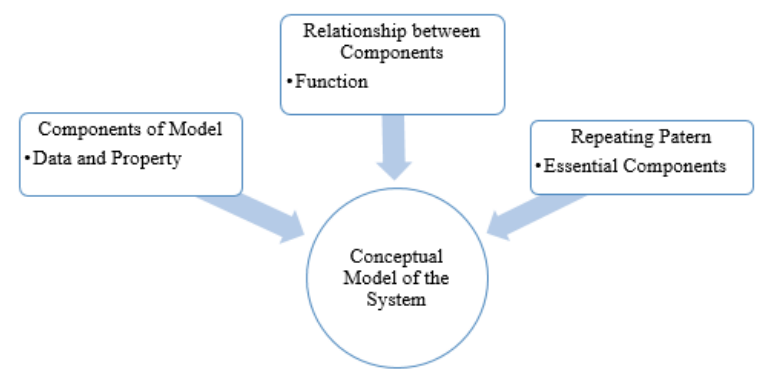

Fig. 2. Mental Models of The System

Data is something that can change if there is a transformation in the component and can be measured, while the property is fixed or attached to the component. Components, data, properties and interaction in Indonesia's capital city relocation are displayed on Table 1.

Table 1. Component, Data, Property and Interaction in Indonesia's Capital City Relocation

\begin{tabular}{|c|c|c|c|}
\hline Components & Data & Property & Interaction \\
\hline Groundwater & $\mathrm{m}^{3}$ & $\begin{array}{c}\text { Water } \\
\text { volume, } \\
\text { Pressure }\end{array}$ & $\begin{array}{c}\text { Land } \\
\text { subsidence, } \\
\text { population, } \\
\text { urbanization, } \\
\text { urban } \\
\text { development, } \\
\text { climate } \\
\text { change, } \\
\text { environmental } \\
\text { quality }\end{array}$ \\
\hline Runoff & $\mathrm{m}^{3}$ & $\begin{array}{c}\text { Water } \\
\text { volume, } \\
\text { Water debit }\end{array}$ & $\begin{array}{c}\text { Drainage, } \\
\text { green open } \\
\text { space, urban } \\
\text { development }\end{array}$ \\
\hline $\begin{array}{c}\text { Green Open } \\
\text { Space }\end{array}$ & Ha & $\begin{array}{c}\text { Area, Number } \\
\text { of Plants }\end{array}$ & $\begin{array}{c}\text { Runoff, Land } \\
\text { use, } \\
\text { population, } \\
\text { urban } \\
\text { development }\end{array}$ \\
\hline
\end{tabular}




\begin{tabular}{|c|c|c|c|}
\hline Drainage & $\mathrm{km}^{2}$ & $\begin{array}{c}\text { Cross- } \\
\text { sectional area }\end{array}$ & $\begin{array}{l}\text { Land use, } \\
\text { green open } \\
\text { space }\end{array}$ \\
\hline $\begin{array}{l}\text { Domestic } \\
\text { Waste }\end{array}$ & $\mathrm{m}^{3}$ & $\begin{array}{c}\text { Waste } \\
\text { generation, } \\
\text { Classification }\end{array}$ & $\begin{array}{l}\text { Population, } \\
\text { urban } \\
\text { development }\end{array}$ \\
\hline $\begin{array}{l}\text { Climate } \\
\text { Change }\end{array}$ & ${ }^{\circ} \mathrm{C} /{ }^{\circ} \mathrm{F}$ & $\begin{array}{c}\text { Temperature, } \\
\text { Increasing sea } \\
\text { level }\end{array}$ & $\begin{array}{c}\text { Population, } \\
\text { green open } \\
\text { space, urban } \\
\text { development, } \\
\text { environmental } \\
\text { quality, } \\
\text { urbanization }\end{array}$ \\
\hline Population & Rate & $\begin{array}{c}\text { Total } \\
\text { Population }\end{array}$ & $\begin{array}{c}\text { Domestic } \\
\text { waste, urban } \\
\text { development }\end{array}$ \\
\hline $\begin{array}{l}\text { Industrial } \\
\text { Area }\end{array}$ & $\mathrm{Ha}$ & $\begin{array}{c}\text { Area, Number } \\
\text { of Industrial } \\
\text { Areas } \\
\end{array}$ & $\begin{array}{c}\text { Population, } \\
\text { environmental } \\
\text { quality, }\end{array}$ \\
\hline Vehicle & $\begin{array}{c}\text { Number } \\
\text { of } \\
\text { Vehicle }\end{array}$ & Total vehicle & $\begin{array}{c}\text { Population, } \\
\text { environmental } \\
\text { quality }\end{array}$ \\
\hline $\begin{array}{c}\text { Commercial } \\
\text { Area }\end{array}$ & $\mathrm{Ha}$ & $\begin{array}{c}\text { Area, Number } \\
\text { of } \\
\text { Commercial } \\
\text { Area } \\
\end{array}$ & $\begin{array}{c}\text { Land use, } \\
\text { urban } \\
\text { development, } \\
\text { population }\end{array}$ \\
\hline Fossil Fuel & Litre & Fuel Volume & $\begin{array}{c}\text { Environmenta } \\
1 \text { quality, } \\
\text { population }\end{array}$ \\
\hline Earthquake & Richter & $\begin{array}{l}\text { Seismic } \\
\text { Activity }\end{array}$ & $\begin{array}{c}\text { Land } \\
\text { subsidence, } \\
\text { landform, } \\
\text { topography, } \\
\text { environmental } \\
\text { quality }\end{array}$ \\
\hline $\begin{array}{c}\text { Urban } \\
\text { Development }\end{array}$ & $\mathrm{Ha}$ & $\begin{array}{c}\text { Number of } \\
\text { Development }\end{array}$ & $\begin{array}{c}\text { Land use, } \\
\text { population }\end{array}$ \\
\hline Urbanization & $\begin{array}{c}\text { Number } \\
\text { of } \\
\text { People }\end{array}$ & $\begin{array}{l}\text { Number of } \\
\text { transmigrant }\end{array}$ & $\begin{array}{c}\text { Population, } \\
\text { land use, } \\
\text { urban } \\
\text { development }\end{array}$ \\
\hline Vegetation & $\mathrm{Ha}$ & - & $\begin{array}{c}\text { Green open } \\
\text { space, runoff, } \\
\text { environmental } \\
\text { quality }\end{array}$ \\
\hline Topography & $\mathrm{m}$ & $\begin{array}{l}\text { Altitude, } \\
\text { Latitude, } \\
\text { elevation }\end{array}$ & $\begin{array}{c}\text { Urban } \\
\text { development } \\
\text { vegetation, } \\
\text { landform }\end{array}$ \\
\hline Landform & - & Classification & $\begin{array}{c}\text { Land } \\
\text { subsidence, } \\
\text { urban } \\
\text { development }\end{array}$ \\
\hline $\begin{array}{c}\text { Environmenta } \\
1 \text { Quality }\end{array}$ & Index & $\begin{array}{l}\text { Air quality, } \\
\text { Water quality }\end{array}$ & $\begin{array}{l}\text { Population, } \\
\text { vegetation, } \\
\text { urban } \\
\text { development, } \\
\text { earthquake, } \\
\text { climate } \\
\text { change, } \\
\text { groundwater, } \\
\text { land } \\
\text { subsidence } \\
\end{array}$ \\
\hline Land use & $\mathrm{Ha}$ & Area & $\begin{array}{c}\text { Runoff, } \\
\text { population, } \\
\text { urban } \\
\text { development }\end{array}$ \\
\hline
\end{tabular}

Components that interacting with each other will establish the repeating pattern. This is because of the interaction can explain the relation of interacting components thus formed a repeating pattern. Repeating pattern from the mental model shown in Fig. 3, such as:

1. Flooding

This repeating pattern is obtained from component: green open space, drainage, domestic waste, climate change, population, urbanization, vegetation, land use, land subsidence, and topography.

2. Pollution

This repeating pattern is obtained from the component: Population, industrial area, vehicle, commercial area, fossil fuel, urban development, urbanization, environmental quality, climate change, groundwater, and vegetation.

\section{Land subsidence}

This repeating pattern is obtained from the component: Groundwater, environmental quality, earthquake, urban development, groundwater, green open space, population, urbanization, topography, land use, and landform.

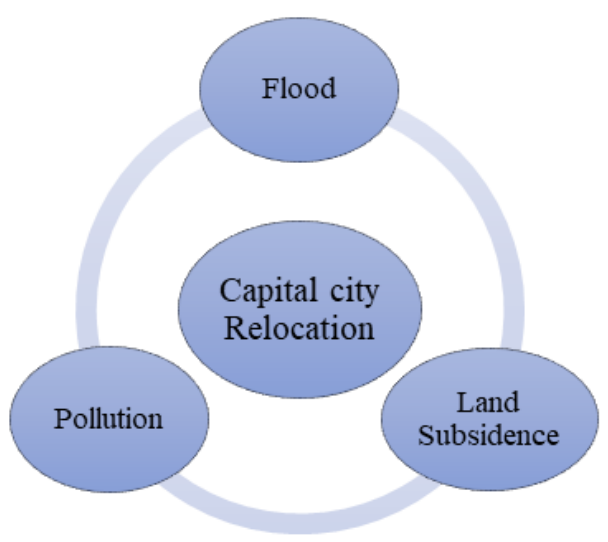

Fig. 3. Repeating Pattern in Capital City Relocation Mental Model

\subsection{Interrelation Model}

Essential components that have been obtained from the mental model then compiled with the interrelation model. The interrelation model shows the simplify of interaction between essential components. Until eventually, decisionmaking formulation can be done through the essential component which gives the most influence (interaction) toward other essential components.

Essential components that compile the model in this study are climate change, flooding, earthquake, land subsidence, environmental quality, urban development, groundwater, pollution, and urbanization. Based on Fig. 4, components of the interrelation model which have a lot of impacts (interactions) toward the other components are environmental quality, urban development, and urbanization. 


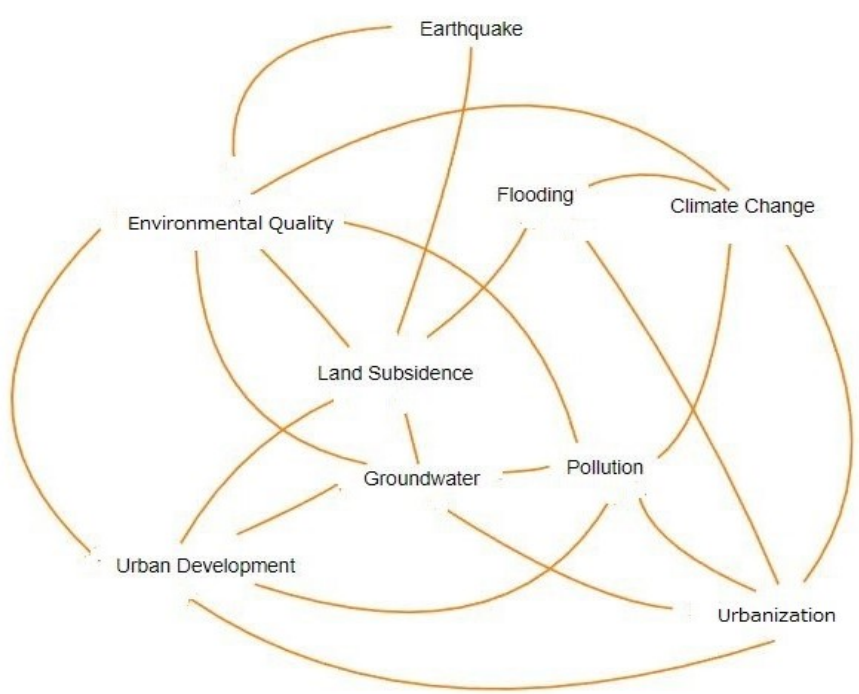

Fig. 4. Interrelation Model about Capital City Relocation Factors

\subsection{System Structure Diagram of Capital City Relocation Factors}

Quality of environment would be affected as Indonesia relocating its capital city. To reduce impact from further environmental and disaster damage, capital city relocation needs to be implemented. Fig 5 summarized basis of capital city relocation from disaster mitigation and environmental damage. Firstly, uncontrolled urbanization rate that currently happened in Jakarta increased Jakarta population significantly, thus urban development will be higher. Urban development also increase air pollution due to rapid industrial development and growth of vehicles as people needs the private transportation rather than using public transportation an. As urban development increase, groundwater resources will be depleted over time due to excessive groundwater discharge, resulting land subsidence. Jakarta is one of the areas with high water stress level due to reducing groundwater resources as uncontrolled usage of the resources. According ministry of energy and mineral resources, the effect of land subsidence and seawater intrusion has been felt by communities around Jakarta. Some part of capital city, particularly in the north region of Jakarta has rapid land subsidence with sea water intrusion damage. It is recorded the land subsidence in Jakarta from $7.5 \mathrm{~cm}$ to $25 \mathrm{~cm}$.

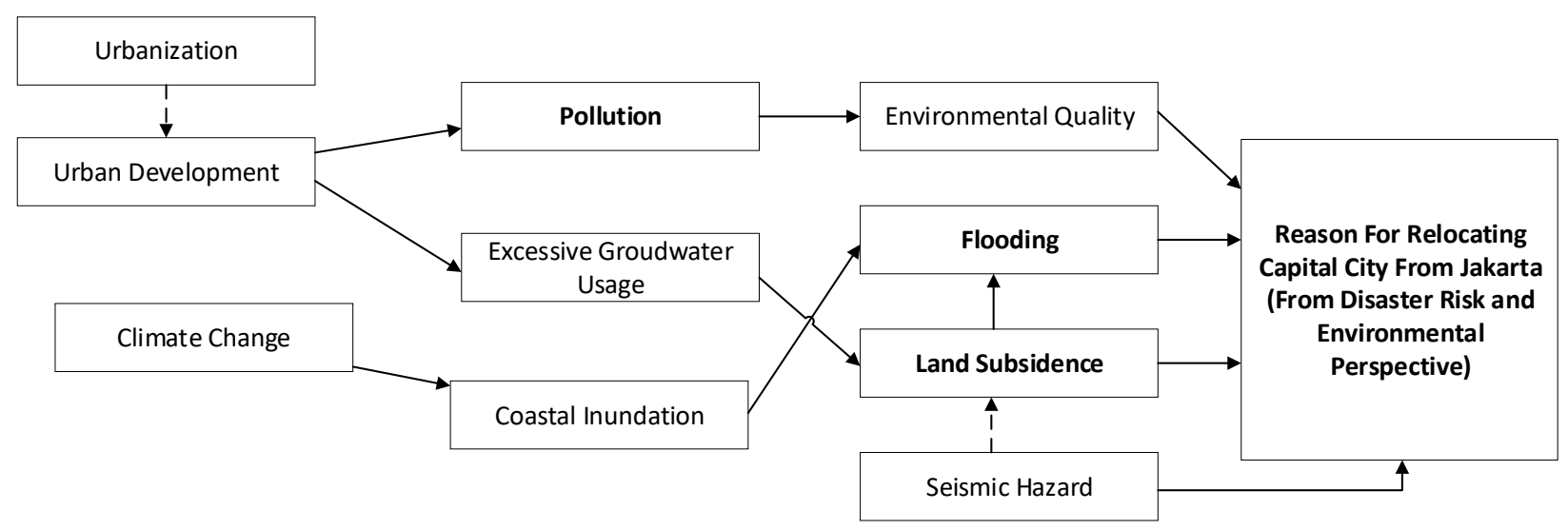

Fig. 5. Structure Diagram in Capital City Relocation

Pollution is the main factor influencing in reduction of environmental quality. One of the measurements for environmental quality for air is Air Quality Index (AQI). Historically, Jakarta has low AQI and consequently become a threat directly to human health (from inhalation). Furthermore, environmental problems such as flooding and land subsidence also become a threat for Jakarta sustainability in the future. Excessive groundwater usage and coastal inundation affecting Jakarta topography, as Jakarta located in the coastal zone and adjacent directly to the sea. As Jakarta located Java, one of the seismically active regions, earthquake effect to capital city cannot be avoided. Referring to data published by Indonesian Agency for Meteorological Climatological and Geophysics (BMKG), in the past two decades, four devastating earthquake has negative 
impact to the community. All those reasons from disaster risk and environmental impacts makes government needs to relocate its capital city.

\subsubsection{System Structure Diagram of Pasca Capital City Relocation}

Capital city relocation risk explained in system structure diagram shown in Fig. 6. Future capital city will have three main problems obtained from most interacted essential components, namely urban development, urbanization and environmental quality. Urban development cannot be avoided, as new capital city needs many buildings and infrastructure. Even though Minister of National Development Planning argues the new capital city in East Kalimantan had low disaster risk from seismic activity, the new designed capital city cannot avoid the risk from forest fires, river inundation, and limited groundwater resources.

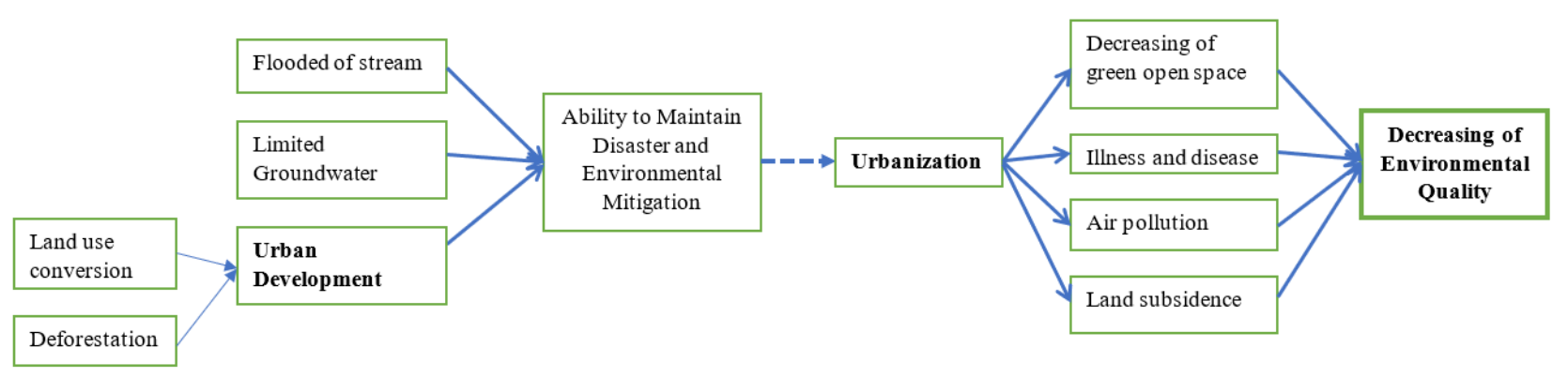

Fig. 6. Capital City Relocation

Disaster and environmental mitigation is an indispensable factor in order to control the effect from excessive urban development, groundwater resources depletion, and river inundation in the future. If the government could maintain disaster and environmental mitigation planning for the future, people will see new designed capital city as promised place and begin to move to East Kalimantan. From the perspective of social psychology, humans tend to choose location with every resources available to fulfill their needs and free from the risk. Obviously, as population increasing from urbanization, green open space will be reduced as the effect of urban development, increased risk of health risk, air pollution caused by vehicles, and land subsidence. Uncontrolled urbanization posed a threat as it would give significant effect in the future, with the consequences of reduced environmental quality.

\section{Conclusion}

Based on preliminary mental model analysis and future disaster risk, the capital city should be relocated to new designed capital city in Kutai Kartanegara Regency alongside with North Penajem Pasar Regency, East Kalimantan as it has lesser disaster risk. As the new capital city undergo urban development process, it should be emphasized important component such environmental quality, controlled urban development based on forest city or smart city, and urbanization to create sustainable capital city for the future. Further mental model analysis including social, politics, economy, homeland security should be taken into consideration to provide better accuracy for decision making.

\section{Limitation}

This research is only limited to mental model framework, relationships between the component and system structure diagram. Further research with system dynamic model software (e.g STELLA/VENSIM) is needed to analyze scenario whether decision for capital city relocation is optimal or redundant.

\section{Acknowledgement}

Author would like to express our gratitude to Dr. Dasapta Erwin Irawan, Dr. Heri Andreas, Dr. Arief Sudrajat, for their insight and ideas to write this journal.

\section{References}

1. H. Z. Abidin, H. Andreas, I. Gumilar, M.D. Azdan, F. Ali, J. Brinkman, Disaster Risk Reduction of Land Subsidence in Jakarta. The 2nd International Workshop on Coastal Subsidence 1 - 17 (2016)

2. H. Z. Abidin, H. Andreas, I. Gumilar, Y. Fukuda, Y.E. Pohan, T. Deguchi, Land subsidence of Jakarta (Indonesia) and Its Relation with Urban Development. Natural Hazards, 59(3), 1753 - 1771 (2011)

3. H. Z. Abidin,, H. Andreas, I. Gumilar, B.D. Yuwono, D. Murdohardono, S. Supriyadi, On Integration of Geodetic Observation Results for Assessment of Land Subsidence Hazard Risk in Urban Areas of Indonesia. In IAG 150 Years, 435 442 (2011)

4. H.Z. Abidin, , R. Djaja, D. Darmawan, S. Hadi, A. Akbar, H. Rajiyowiryono, C. Subarya, Land Subsidence of Jakarta (Indonesia) and Its Geodetic 
Monitoring System. Natural Hazards, 23(2/3), 365 - 387 (2001)

5. H. Andreas, H.Z. Abidin, D.A. Sarsito, D. Pradipta, Adaptation of 'Early Climate Change Disaster' to the Northern Coast of Java Island Indonesia. Engineering Journal, 22(3), 207 - 219 (2018)

6. P. Bettinger, K.A. Boston, Conceptual Model for Describing Decision-Making Situations in Integrated Natural Resource Planning and Modeling Projects. Environmental Management Journal, 28 (1) 1 - 7 (2001)

7. E. Chaussard, F. Amelung, H. Abidin, S.H. Hong, Sinking cities in Indonesia: ALOS PALSAR Detects Rapid Subsidence Due to Groundwater and Gas Extraction. Remote Sensing of Environment, 128150 - 161 (2016)

8. A. Cipta, P. Cummins, M. Irsyam, S. Hidayati, Basin Resonance and Seismic Hazard in Jakarta, Indonesia, Geosciences (Switzerland), 8(4) 1-25 (2018)

9. N.S. Darmanto, A.C.G. Varquez, N. Kawano, M. Kanda, Future Urban Climate Projection in a Tropical Megacity Based on Global Climate Change and Local Urbanization Scenarios, Urban Climate, 29 (2019)

10. T. Firman, I.A.I. Dharmapatni,. The Challenges to Sustainable Development in Jakarta Metropolitan Region. Habitat International, 18(3) 79-94 (1994)

11. T. Firman, I.M. Surbakti, I.C. Idroes, H.A. Simarmata, Potential Climate-Change Related Vulnerabilities in Jakarta: Challenges and Current Status, Habitat International, 35(2) 372 - 378 (2011)

12. R. Hall, Hydrocarbon Basins in SE Asia: Understanding Why They are There, Petroleum Geoscience, 15(2) 131 - 146 (2009)

13. A.H. Harsolumakso, Struktur Geologi dan Daerah Genangan. Buletin Geologi, 33(1) 29 - 45 (2001)

14. Hutasoit, L. M. Kemungkinan Hubungan antara Kompaksi Alamiah dengan Daerah Genangan Air di DKI Jakarta. Buletin Geologi, 33(1) 21 - 28 (2001)

15. A. Koulali, S. McClusky, S. Susilo, Y. Leonard, P. Cummins, P. Tregoning, A.B. Wijanarto, The Kinematics of Crustal Deformation in Java from GPS Observations: Implications for Fault Slip Partitioning, Earth and Planetary Science Letters, 45869 - 79 (2017)

16. Y. Kwon, Sejong Si (City): are TOD and TND Models Effective in Planning Korea's New Capital. The International Journal of Urban Policy and Planning, 42242 - 257 (2015)

17. H. Latief, M.R. Putri, F. Hanifah, I.N. Afifah, M. Fadli, D.O. Ismoyo, Coastal Hazard Assessment in Northern Part of Jakarta. Procedia Engineering, 212 $1279-1286$ (2018)

18. D. Murdohardono, U. Sudarsono, Land Subsidence Monitoring System in Jakarta. In Proceedings of Symposium on Japan-Indonesia IDNDR Project : Volcanology, Tectonics, Flood and Sediment Hazards, 243 - 256 (1998)
19. D. Murdohardono, H. Tirtomihardjo, Penurunan Tanah di Jakarta dan Rencana Pemantauannya. In Proceedings of the 22nd Annual Convention of the Indonesian Association of Geologists, 346-354 (1993)

20. U. C. Nkwunonwo, M. Whitworth, B. Baily, Review Article: A Review and Critical Analysis of The Efforts Towards Urban Flood Risk Management in The Lagos Region of Nigeria. Natural Hazards Earth System Science, 16349 369 (2016)

21. Pusat Studi Gempa Nasional (National Center for Earthquake Studies). Peta Sumber dan Bahaya Gempa Indonesia Tahun 2017. (Pusat Litbang Pemukiman PU, Bandung, 2017)

22. R. Putratama, Aktivitas Gempa di Pulau Kalimantan Paling Rendah. Retrieved August 28, 2019, from https://www.bmkg.go.id/pressrelease/?p=aktivitas-gempa-di-pulau-kalimantanpaling-rndah\&tag=press-release\&lang=ID (2019)

23. W. J. F. Simons, A. Socquet, C. Vigny, B. A. C. Ambrosius, S. H. Abu, C. Promthong, W. Sakman, A Decade of GPS in Southeast Asia: Resolving Sundaland Motion and Boundaries. Journal of Geophysical Research: Solid Earth, 112(6) 1 - 20 (2007)

24. Sterman, J. D., Business Dynamics: Systems Thinking and Modeling for a Complex Word. (McGraw-Hill, New York, 2000)

25. H. Takagi, M. Esteban, T. Mikami, D. Fujii, Projection of Coastal Floods in 2050 Jakarta. Urban Climate, 17135 - 145 (2016) 